\title{
Sistem Pengambilan Keputusan Pemberian Kredit Modal Kerja Menggunakan Metode Naïve Bayesian Classification Berbasis WEB
}

\author{
Sayed Fachrurrazi ${ }^{1}$, Defry Hamdhana ${ }^{2}$, Maulidawati ${ }^{3}$ \\ Jurusan Teknik Informatika, Fakultas Teknik, Universitas Malikussaleh \\ sayedfachrurrazi@unimal.ac.id
}

\begin{abstract}
Abstrak
Abstrak - Sebagai lembaga keuangan Bank Aceh Syariah Cabang Samudera Lhokseumawe yang menerima simpanan nasabah dalam bentuk tabungan, giro dan deposito serta melayani pinjaman berupa kredit oleh pihak lain yang akan dikembalikan pada waktu tertentu dengan jumlah bunga yang telah ditetapkan. Permasalahan terkait dengan pemberian kredit modal kerja, seperti pengajuan apakah nasabah tersebut layak atau tidak layak mendapatkan kredit modal kerja. Untuk mengatasi masalah tersebut dapat diselesaikan dengan metode Naïve Bayesian Classification. Dalam penentuan pemberian kredit modal kerja kepada calon debitur terdapat beberapa kriteria yang menjadi penilaian seperti karakter nasabah, umur, jaminan, penghasilan, jumlah pinjaman, lama usaha, modal, dan pekerjaan. Sistem pengambilan keputusan pemberian kredit modal kerja berbasis web ini dibangun dengan menggunakan pemodelan DFD (Data Flow Diagram) dan bahasa pemograman PHP dan database MySQL. Berdasarkan hasil analisis dengan menggunakan metode Naïve Bayesian Classification, maka dapat membantu pihak bank dalam memutuskan sebuah pengajuan pemberian kredit modal kerja serta dapat dilakukan dengan mudah. Hasil pengujian dari 45 data nasabah, maka 88,89\% dinyatakan layak menerima kredit modal kerja dan $11,11 \%$ dinyatakan tidak layak menerima kredit modal kerja.
\end{abstract}

Kata kunci : Sistem pendukung keputusan, Naïve Bayesian Classification, kredit modal kerja, Bank Aceh Syariah Cabang Samudera Lhokseumawe.

DOI: https://doi.org/10.29103/techsi.v11i1.1401 


\section{Pendahuluan}

Kegiatan ekonomi masyarakat dan perekonomian suatu Negara secara keseluruhan tidak bisa terlepas dari dunia perbankan. Peranan perbankan untuk memajukan perekonomian suatu Negara dalam dunia modern ini sangatlah besar. Bank pada dasarnya merupakan industri sejenis di mana seluruh bank dapat menawarkan dan melayani berbagai jenis produk, baik itu produk yang berbeda maupun produk yang sama. Bank dilihat dari segi persaingan antara yang satu dengan yang lain setiap jenis produk atau jasa yang sama dapat dimodifikasi sedikit atau sepenuhnya, walaupun produk atau jasa tersebut sudah ada. Hal ini merupakan salah satu strategi yang dibuat oleh bank untuk menarik minat nasabah. (Imroatul Khasanah, Achmad Husaini, dkk, 2013)

Aktivitas pelayanan kredit di anggap sangat penting dan strategis dalam perkembangan perbankan serta mengakibatkan pengelolaan kredit menjadi titik perhatian utama bagi manajemen sehingga tujuan utama pengelolaan kredit adalah agar bank dapat memaksimalkan kesehatan kinerja dari bank itu sendiri dengan cara meningkatkan kuantitas dan kualitas kredit. Kuantitas kredit di lihat dan di nilai dari jumlah dan tingkat pertumbuhan kredit yang disalurkan, sedangkan kualitas kredit secara sederhana dan singkat dapat di ukur dari jumlah dan porsi kredit macet atau bermasalah (non performing lans). (Febri Karauwan, 2012)

Modal kerja merupakan aspek yang paling penting bagi tiap perusahaan karena modal kerja merupakan faktor penentu berjalannya kegiatan operasional dalam jangka pendek dalam perusahaan. Kegiatan operasional tersebut berpengaruh pada pendapatan yang diperoleh perusahaan. Perusahaan yang mampu menghasilkan nilai tambah atau keuntungan yang sustainable (berkelanjutan) adalah perusahaan yang mampu memanfaatkan modal kerjanya secara efektif dan efisien. Kesalahan atau tidak efektifnya pengelolaan modal kerja bisa menyebabkan menurunnya performa operasional perusahaan. (Clairene E.E. Santoso, 2013)

Pengukuran keberhasilan pengelolaan modal kerja dapat menggunakan rasio perputaran modal kerja. Dengan 
Sistem Pengambilan Keputusan Pemberian Kredit Modal Kerja

menggunakan Metode Naïve Bayesian Classification

berbasis WEB

menggunakan rasio ini dapat diketahui efektifitas penggunaan modal kerja perusahaan pada satu periode tertentu, yaitu apakah perusahaan memanfaatkan modal kerjanya dengan baik sehingga bisa menghasilkan keuntungan bagi perusahaan atau malah sebaliknya. Mengukur perputaran modal kerja adalah membandingkan penjualan bersih perusahaan dengan modal kerjanya selama satu periode, sehingga melalui rasio ini dapat diketahui apabila semakin tinggi perputaran modal kerja maka semakin efektif. (Clairene E.E. Santoso, 2013).

\section{Metode Penelitian}

2.1. Naive Bayesian Classificition

Kaitan antara Naïve Bayes dengan klasifikasi, korelasi hipotesis dan bukti klasifikasi adalah bahwa hipotesis dalam Teorema Bayes merupakan label kelas yang menjadi target pemetaan dalam klasifikasi, sedangkan bukti merupakan fiturfitur yang menjadikan masukkan dalam model klasifikasi. Jika $X$ adalah vektor masukkan yang berisi fitur dan $Y$ adalah label kelas, Naïve Bayes dituliskan dengan $\mathrm{P}(\mathrm{X} \mid \mathrm{Y})$. Notasi tersebut berarti probabilitas label kelas $\mathrm{Y}$ didapatkan setelah fitur-fitur $\mathrm{X}$ diamati. Notasi ini disebut juga probabilitas akhir (posterior probability) untuk $\mathrm{Y}$, sedangkan $\mathrm{P}(\mathrm{Y})$ disebut probabilitas awal (prior probability) Y. Selama proses pelatihan harus dilakukan pembelajaran probabilitas akhir $\mathrm{P}(\mathrm{Y} \mid \mathrm{X})$ pada model untuk setiap kombinasi $\mathrm{X}$ dan $\mathrm{Y}$ bedasarkan informasi yang didapat dari data latih. Dengan membangun model tersebut, suatu data uji $X^{\prime}$ dapat diklasifikasikan dengan mencari nilai $Y^{\prime}$ dengan memaksimalkan nilai $P\left(X^{\prime} \mid Y^{\prime}\right)$ yang didapat. (Fachry Husaini, 2013).

Formulasi Naïve Bayes untuk klasifikasi adalah :

$\mathrm{P}(\mathrm{Y} \mid \mathrm{X})=\left(\mathrm{P}(\mathrm{Y}) \Sigma_{-}(\mathrm{i}=1)^{\wedge} \mathrm{q}_{\text {w.W. }} \llbracket \mathrm{P}(\mathrm{Xi} \mid \mathrm{Y}) \rrbracket\right) /(\mathrm{P}(\mathrm{X}))$

Keterangan :

$\mathrm{P}(\mathrm{Y} \mid \mathrm{X}) \quad$ : probabilitas data dengan vektor $\mathrm{X}$ pada kelas Y

$\mathrm{P}(\mathrm{Y}) \quad$ : probabilitas awal kelas $\mathrm{Y}$ 


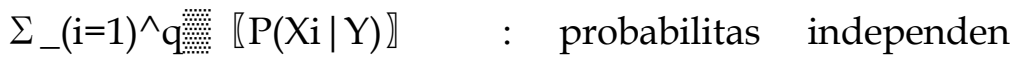
kelas $Y$ dari semua fitur dalam vektor $X$ $\mathrm{P}(\mathrm{X})$ : probabilitas $\mathrm{X}$

Dalam perhitungan prediksi nantinya kita tinggal menghitung bagian $\mathrm{P}(\mathrm{Y}) \Sigma_{-}(\mathrm{i}=1)^{\wedge} \mathrm{q}_{\text {w }} \llbracket \mathrm{P}\left(\mathrm{Xi}_{\mathrm{i}} \mid \mathrm{Y}\right) \rrbracket$ dengan memilih yang terbesar sebagai kelas yag dipilih sebagai hasil prediksi. Sementara

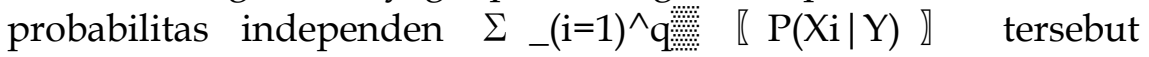
merupakan pengaruh semua fitur dari data terhadap setiap kelas $Y$, yang dinotasikan dengan :

$$
\mathrm{P}(\mathrm{X} \mid \mathrm{Y}=\mathrm{y})=\Sigma_{-}(\mathrm{i}=1) \wedge \mathrm{q} \text {. }
$$

Setiap set fitur $X=\{X 1, X 2, X 3, \ldots, X q\}$ terdiri atas $q$ atribut $(q$ dimensi).

Umumnya, Bayes mudah dihitung untuk fitur bertipe kategori seperti pada kasus klasifikasi hewan dengan fitur "penutup kulit" dengan nilai \{bulu, rambut, cangkang\} atau kasus fitur "jenis kelamin" dengan nilai \{pria, wanita\}. Namun untuk fitur dengan tipe numerik (kontinu) ada perlakuan khusus sebelum dimasukkan dalam Naïve Bayes. Caranya adalah :

1. Melakukan diskretisasi pada setiap fitur kontinu dan mengganti nilai fitur kontinu tersebut dengan nilai interval diskret. Pendekatan ini dilakukan dengan mentransformasikan fitur kontinu ke dalam fitur ordinal.

2. Mengasumsikan bentuk tertentu dari distribusi probabilitas untuk fitur kontinu dan memperkirakan parameter distribusi dengan data pelatihan. Distribusi Gaussian biasanya dipilih untuk merepresentasikan probabilitas bersyarat dari fitur kontinu pada sebuah kelas $\mathrm{P}(\mathrm{Xi} \mid \mathrm{Y})$, sedangkan distribusi Gaussian dikarakteristikkan dengan dua parameter : mean, $\mu$ dan varian, $\sigma 2$. Untuk setiap kelas $\mathrm{yj}$, probabilitas bersyarat kelas yj untuk fitur $\mathrm{Xi}$ adalah :

$$
\begin{aligned}
& \mathrm{P}\left(\mathrm{X} \_\mathrm{i}=\mathrm{x} \_\mathrm{i} \quad \mid \mathrm{Y}=\mathrm{y} \_\mathrm{j}\right)=1 / \sqrt{2} 2 \text { поij } \exp \quad \llbracket\left(\left(\mathrm{x} \_\mathrm{i}-\mu_{-}(\mathrm{ij})\right)^{\wedge} 2\right) /(2 \rrbracket \\
& \left.\mathrm{o}^{\wedge} 2 \rrbracket-\mathrm{ij}\right) \text { 『 }
\end{aligned}
$$

Keterangan : 
$P$ : Peluang

$\mathrm{X} \_\mathrm{i} \quad$ : Atribut ke i

$\mathrm{x \_}$ i $\quad$ Nilai atribut ke i

$\mathrm{Y} \quad$ : Kelas yang dicari

y_j : : Sub kelas yang dicari

$\mu \quad$ : Mean, menyatakan rata - rata dari seluruh atribut

o : Devisi standar, menyatakan varian dari seluruh atribut

Parameter $\mu \_i j$ bisa didapat dari mean sampel $\llbracket X \rrbracket \_i(x)$ dari semua data latih yang menjadi milik kelas yj, sedangkan 【o^2】 _ij dapat diperkirakan dari varian sampel $\left(s^{\wedge} 2\right)$ dari data latih.Analisa kebutuhan

\subsection{Kebutuhan Proses}

Setelah data-data yang dibutuhkan sistem di input, maka selanjutnya data-data tersebut akan diproses untuk memperoleh penilaian berdasarkan algoritma Naive Bayesian Classification yang digunakan sampai akhirnya proses menentukan solusi yang dicari.

Ada beberapa prinsip penilaian pemberian kredit modal kerja untuk menilai nasabah apakah nasabah tersebut dapat memperoleh kredit modal kerja dengan menggukan analisa yaitu:

1. Karakter nasabah. Penilaian karakter nasabah diperoleh dari informasi Bank lain apabila pernah melakukan peminjaman maka nama nasabah tersebut sudah terdaftar di BI Checking (SID).

2. Umur

3. Jaminan. Jaminan dibutuhkan untuk berjaga-jaga seandainnya nasabah tidak dapat mengembalikan pinjamannya.

4. Penghasilan

5. Jumlah pinjaman

6. Lama usaha

7. Modal

8. Pekerjaan 


\subsection{Skema Sistem}

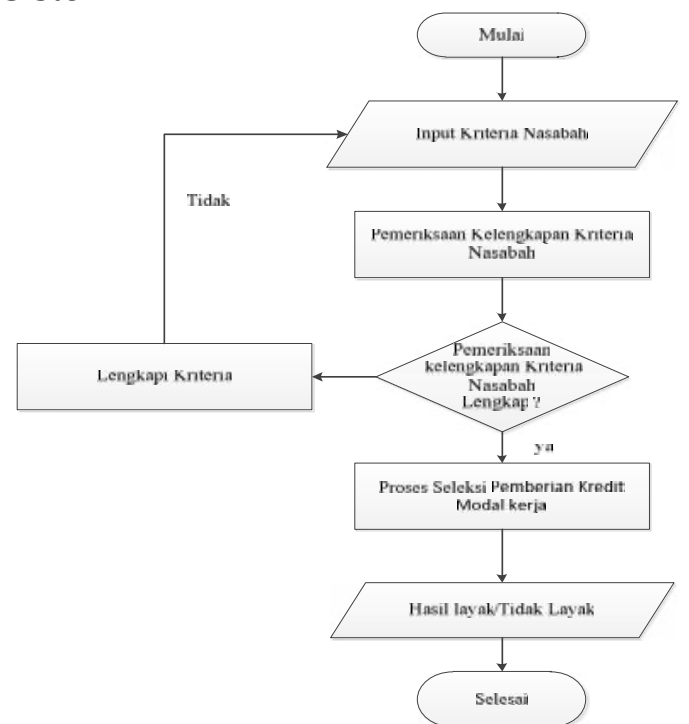

Gambar 2.1. Skema Sistem Metode Naïve Bayesian Classification

Pertama yang dilakukan adnin adalah melakukan login setelah login sukses maka admin akan meng input kriteria nasabah berupa, karakter, umur, jaminan, penghasilan, jumlah pinjaman, lama usaha, modal, dan pekerjaan. Selanjutnya akan dilakukan proses pemeriksaan kriteria nasabah bila kriteria nasabah tidak lengkap maka sistem akan kembali ke input kriteria nasabah, jika kriteria lengkap maka sistem akan melakukan proses seleksi pemberian kredit modal kerja dan hasil nya berupa layak/tidak layak.

\section{Hasil dan Pembahasan}

Setelah mengetahui analisis kebutuhan dari user, dapat di tentukan rancangan aktifitas.

3.1. Nilai Atribut 
Sistem Pengambilan Keputusan Pemberian Kredit Modal Kerja menggunakan Metode Naïve Bayesian Classification

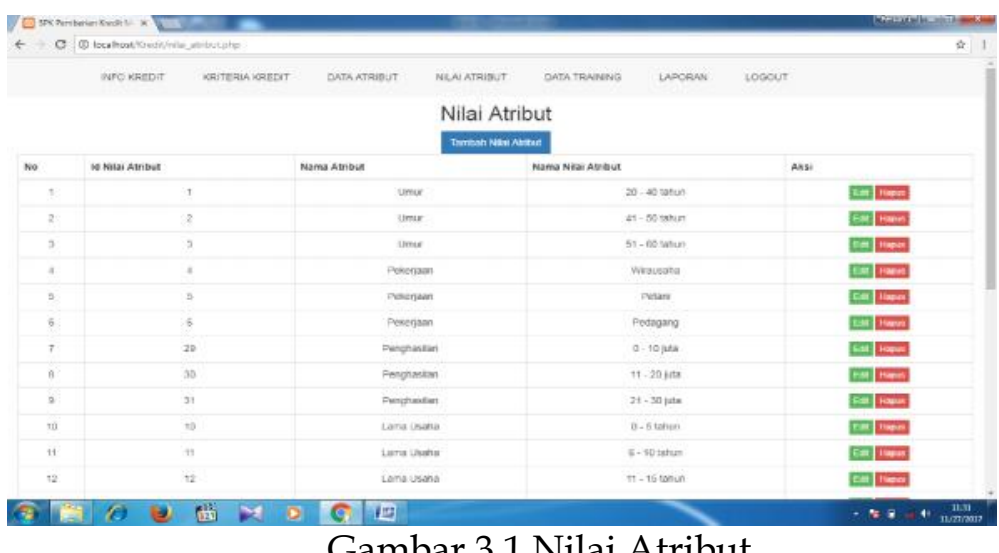

Gambar 3.1 Nilai Atribut

Nilai atribut fungsinya untuk menambahkan nilai atribut. Dalam nilai atribut ada no, id nilai atribut, nama atribut, nama nilai atribut dan aksi. Admin dapat menambahkan nilai atribut dengan mengklik batton tambah nilai atribut serta data yang sudah disimpan bisa diedit dan dihapus.

\subsection{Data Training}

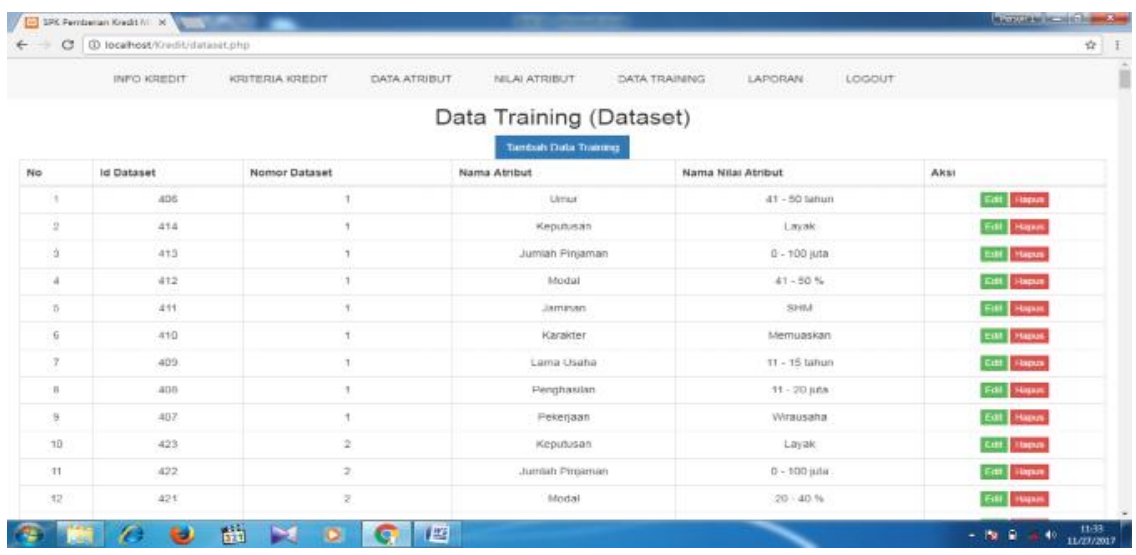

Gambar 3.2. Data Training

Data training fungsinya untuk menambahkan data training. Dalam form data training ada no, id dataset, nomor dataset, nama 
atribut, nilai atribut dan aksi. Admin dapat menambahkan data training dengan mengklik batton tambah data training serta data yang sudah disimpan bisa diedit dan dihapus.

\subsection{Laporan}

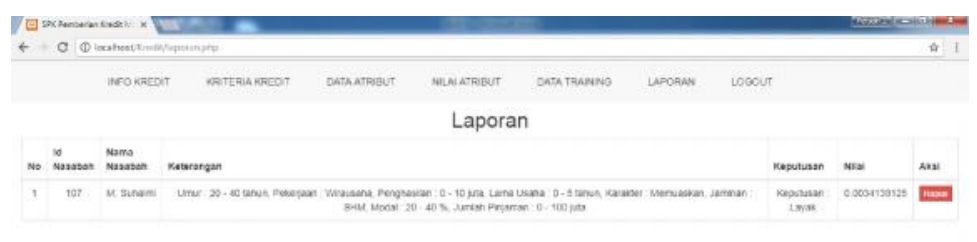

Gambar 3.3. Laporan

Untuk laporan adalah data-data yang sudah diinput oleh admin, admin bisa melihat siapa saja nasabahnya yang mengambil kredit modal kerja. Didalam laporan ada no, id dari nasabah, nama nasabah, keterangan dari data nasabah yang diinput oleh adamin, keputusan nasabah tersebut layak atau tidak layak menerima kredit modal kerja, nilai hasil dari pencarian metode naïve bayesian classification dan aksi. Untuk aksi admin bisa menghapus data yang ada di laporan dan admin juga bisa cetak laporan tersebut.

\section{Kesimpulan}

Dari hasil penelitian dan pembahasan yang telah dilakukan dapat disimpulkan bahwa:

1. Dengan menerapkan sistem pengambilan keputusan pemberian kredit modal kerja dengan menggunakan metode Naïve Bayesian Classification, sistem ini dapat mengurangi tingkat kerumitan perhintungan dari proses input data pemberian kredit modal kerja, serta mempercepat waktu dan 
mempermudahkan karyawan bagian pemberian kredit modal kerja dalam mengolah data laporan dan juga untuk meningkatkan kinerja Bank Aceh Syariah Cabang Samudera Lhokseumawe menjadi maksimal dan lebih baik.

2. Sistem pemberian kredit modal kerja menggunakan metode naïve Bayesian classification

3. Sistem pemberian kredit modal kerja menggunakan metode naïve Bayesian classification menampilkan output layak atau tidak layak menerima kredit modal kerja untuk nasabah yang mengajukan pemberian kredit modal kerja. 


\section{Daftar Pustaka}

Husaini Fachry, 2016. Algoritma Klasifikasi Naive Bayes untuk Menilai Kelayakan Kredit (Studi Kasus : Bank Mandiri Kredit Mikro). Program Studi Teknik Informatika-Universitas Muhammadiyah Jamber. Diakses 1 Juni 2017.

Kasmir, 2012. Analisis Laporan Keuangan. Rajawali Pers: Jakarta.

Khasanah Imroatul, Husaini Achmad, Azizah Devi Farah, 2013. Sistem prosedure pemberian kredit modal kerja dalam upaya meminimalisir tunggakan kredit. Fakultas Ilmu Administrasi Negara Universitas Brawijaya. Diakses tanggal 23 Juli 2017.

Santoso Clairene E.E, 2013. Perputaran Modal Kerja Dan Perputaran piutang Pengaruhnya Terhadap Profitabilitas Pada PT. Pegadaian (Persero). Diakses Tanggal 15 Oktober 2016). 